\title{
Protective effects of garlic (Allium sativum) and ginger (Zingiber officinale) on physicochemical and microbial attributes of liquid smoked silver carp (Hypophthalmichthys molitrix) wrapped in aluminium foil during chilled storage
}

\author{
Fijelu Frank, Yanshun Xu, Qixing jiang and Wenshui Xia* \\ School of Food Science and Technology, Jiangnan University, Wuxi, Jiangsu 214122, China.
}

Accepted 7 November, 2013

\begin{abstract}
The antioxidant and antimicrobial effects of equivalent concentrations of both garlic and ginger separately in fresh and powder form on quality attributes of liquid smoked silver carp (Hypophthalmichthys molitrix) during chilled storage were investigated for a period of 24 days. The control and the treated fish samples were analysed periodically for microbiological (total viable count) and physicochemical ( $\mathrm{pH}$, colour, water activity, free fatty acid, total volatile basic nitrogen; TVB-N, 2thiobarbituric acid-reactive substances; TBARS) characteristics. The results showed that each spice in either fresh or powder form treatment significantly $(P<0.05)$ reduced growth of microorganisms as reflected in total viable counts (TVC) from day 6 of storage, lipid oxidation decrease as displayed in TBARS, chemical spoilage decrease as reflected in TVB-N after day 6 of storage as compared to the control samples. The results obtained from this study suggests that garlic and ginger in fresh and powder form, through their combined antioxidant and antimicrobial effects, are potentially useful in preserving liquid smoked silver carp at $4 \pm 1^{\circ} \mathrm{C}$.
\end{abstract}

Key words: Liquid smoke, silver carp, spices, shelf life, chilled storage.

\section{INTRODUCTION}

Silver carp (Hypophthalmichthys molitrix) is a prevalent freshwater fish, it has been one of the most widely cultured species all over the world due to its fast growth rate, easy cultivation and high feed efficiency ratio (Hu et al., 2008). This species is also known to provide a high content of important constituents of the human diet such as nutritional and readily digestible proteins, lipid, soluble vitamins, microelements and polyunsaturated fatty acids (Erkan and Ozden, 2007). However, distributors face challenges of deterioration during postmortem storage and processing as a result of damage mechanisms such as autolytic degradation, microbiological spoilage and lipid oxidation (Naseri and Rezaei, 2012).

Fish smoking is one of the oldest method of preservation, giving a characteristic flavour and colour to the product and increasing its shelf life. The preservative effect is due to the presence of some antimicrobial compounds in smoke such as phenols and formaldehyde (Muratore and Licciardello, 2005). Nevertheless, the conventional smoking process is commonly substituted by the use of liquid smoke (Hattula et al., 2001). Liquid smoke contains the same functional components such as phenols, carbonyls 
and acids that are found in vaporous smoke. Liquid smoke is free of harmful compounds such as polycyclic aromatic hydrocarbons (PAHs) which are ubiquitous environmental contaminants; these are commonly found in convectional smoke, also considered carcinogenic and mutagenic molecules (Alcicek, 2013). Additional advantages of liquid smoke are environmental friendliness, lower cost and easy application such as direct addition, drenching or dipping, impregnated (smoked) casings and atomization (Varlet et al., 2007). The smoking process is often coupled with other treatments, such as salting, addition of spices, packaging techniques and chilled storage, to produce synergistic effects on spoilage microorganisms and to increase shelf life (Visciano et al., 2008).

Ginger and garlic are spices, in addition to contributing taste and aroma to foods, also contain a variety of bioactive substances which are of considerable use from the standpoint of food science and technology. These may be used singly or in combination, and some act synergistically to control spoilage of foods, these have made it to be used as bio preservative (Yanishlieva et al., 2006). Recently, use of plant extracts as natural antioxidants has gained increasing interest because of the global trend of restriction in use of synthetic substances, also antioxidant rich plant extracts have potential benefits in food preservations (Uhart et al., 2006).

The aim of this study was to investigate the antioxidant as well as the antimicrobial effect of equivalent concentrations of two garlic and ginger preparations (fresh and powder form) on shelf life of liquid smoked silver carp wrapped in aluminum foil and stored at $4 \pm 1^{\circ} \mathrm{C}$ by determining microbiological and physicochemical differences.

\section{MATERIALS AND METHODS}

Fresh garlic bulbs (Allium sativum, Chinese white garlic) and fresh ginger (Zingiber officinale, Chinese yellow ginger) were purchased from a local market. The dry skin of both fresh garlic and ginger were removed before use; they were peeled and crushed finely by using a kitchen hand held grater (Evasolo). Garlic powder and ginger powder were purchased from a supermarket. $4 \mathrm{~kg}$ of produced garlic powder was the weight equivalent of $16 \mathrm{~kg}$ of fresh garlic, also $2 \mathrm{~kg}$ of produced ginger powder was the weight equivalent of $10 \mathrm{~kg}$ of fresh ginger, according to the manufacturer details.

\section{Preparation of fish}

fifteen silver carp (H. molitrix) with average weight of $815.12 \pm$ $14.55 \mathrm{~g}$ were purchased from a local market (Wuxi, Jiangsu, China), transported within $1 \mathrm{~h}$ in sealed polystyrene foam boxes containing ice to the Food Processing Technology Laboratory at Jiangnan University, where processing was carried out, then randomly divided into 5 groups for further treatments after they were gutted, eviscerated, deboned, the scale, skin, pin bones, debris were removed, and filleted.

\section{Sample treatment and brining with liquid smoke}

C: The samples without ginger and garlic treatment; T1: $10 \mathrm{~g} / \mathrm{kg}$ ginger powder was added to brine; T2: $50 \mathrm{~g} / \mathrm{kg}$ of fresh ginger applied on fish for $4 \mathrm{~h}$ at $4 \pm 1^{\circ} \mathrm{C}$ after brining; T3: $12.5 \mathrm{~g} / \mathrm{kg}$ garlic powder was added to the brine; $74: 50 \mathrm{~g} / \mathrm{kg}$ of fresh garlic was applied on the fish for $4 \mathrm{~h}$ at $4 \pm 1^{\circ} \mathrm{C}$ after brining.

All the samples above were immersed in brine containing $10 \%$ sodium chloride and $1 \%$ liquid smoke solution at a ratio of $1: 1(\mathrm{w} / \mathrm{w})$ for $4 \mathrm{~h}$ at $4 \pm 1^{\circ} \mathrm{C}$.

\section{Drying, heating and cooling of samples}

All samples were air dried at $20^{\circ} \mathrm{C}$ for $40 \mathrm{~min}$. The samples were then heated in an oven at $75^{\circ} \mathrm{C}$ for $80 \mathrm{~min}$. After cooling at $20^{\circ} \mathrm{C}$ for $30 \mathrm{~min}$, the smoked products were wrapped in aluminium foil, and stored at $4 \pm 1^{\circ} \mathrm{C}$ until analysis performed in replicates on day 0,6 , 12,18 and 24 of storage.

\section{$\mathrm{pH}$ value measurement}

A $1 \mathrm{~g}$ sample of the fish flesh was homogenized in $10 \mathrm{~mL}$ of distilled water and the mixture was filtered. The $\mathrm{pH}$ of the filtrate was measured according to the method of Vyncke (1981) using a pH meter (Mettler Toledo 320-s, Shanghai, China).

\section{Water activity}

An adequate amount of ground sample was placed in a holding cup (about one-half full) and the water activity was read (AQUA LAB CX-2, Decagon Devices Inc, Pullman, WA, USA) after equilibration at $25^{\circ} \mathrm{C}$.

\section{Color evaluation}

The color of fish was measured using the $L^{*}, a^{*}, b^{*}$ mode of CIE using color meter (Model TC-P $\alpha$ G, Beijing optical Instruments Factory, Beijing, China). The measurement of $L^{*}$ (indicator of lightness), $a^{*}$ (indicator of redness), $b^{*}$ (indicator of yellowness) was performed in two replications (Lanier et al., 1991).

\section{Determination of total volatile basic nitrogen (TVB-N)}

TVB-N was determined according to the method of Antonacopoulos and Vyncke (1989). For total TVB-N, fish muscle (10 g) was homogenized with $6 \%$ perchloric acid $(90 \mathrm{~mL})$ for $1 \mathrm{~min}$ in an IKA T25 basic Ultra-Turrax (Janke \& Kunkel, IKA Labor-technik, Selangor, Malaysia). The homogenates were filtered through a filter paper (Whatman no. 1) and filtrates alkalized by $\mathrm{NaOH}(20 \%)$. The distillate was titrated with $0.01 \mathrm{~N} \mathrm{HCl}$.

\section{Determination of free fatty acid (FFA) content}

Free fatty acid content of the fish samples was determined according to the method of Kirk and Sawyer (1991). A mixture of diethyl ether $(25 \mathrm{~mL})$, ethanol $(70 \% \mathrm{v} / \mathrm{v})(25 \mathrm{~mL})$ and $1 \%$ phenolphthalein solution $(1 \mathrm{~mL})$ was prepared then neutralized with $0.1 \mathrm{M} \mathrm{NaOH}$ solution. Two grams quantities of fish samples were blended in the neutral solvent prepared above for about $20 \mathrm{~min}$, and then titrated with $0.1 \mathrm{M} \mathrm{NaOH}$ with constant shaking until a pink color was formed which persisted for about $15 \mathrm{~s}$. All samples were analyzed in triplicate and the free fatty acid content was expressed 
Table 1. $\mathrm{pH}$.

\begin{tabular}{lccccc}
\hline \multirow{2}{*}{ Storage time(days) } & \multicolumn{5}{c}{$\mathbf{p H}$} \\
\cline { 2 - 6 } & $\mathbf{C}$ & $\mathbf{T 1}$ & $\mathbf{T 2}$ & $\mathbf{T 3}$ & T4 \\
\hline 0 & $6.07 \pm 0.54^{\mathrm{aA}}$ & $6.1 \pm 0.18^{\mathrm{aA}}$ & $6.15 \pm 0.07^{\mathrm{aA}}$ & $6.18 \pm 0.25^{\mathrm{aA}}$ & $6.07 \pm 0.09^{\mathrm{aA}}$ \\
6 & $6.25 \pm 0.26^{\mathrm{aA}}$ & $6.23 \pm 0.04^{\mathrm{aAB}}$ & $6.19 \pm 0.44^{\mathrm{aA}}$ & $6.2 \pm 0.12^{\mathrm{aA}}$ & $6.13 \pm 0.13^{\mathrm{aA}}$ \\
12 & $6.35 \pm 0.08^{\mathrm{aA}}$ & $6.3 \pm 0.14^{\mathrm{aA}}$ & $6.26 \pm 0.01^{\mathrm{aA}}$ & $6.3 \pm 0.45^{\mathrm{aA}}$ & $6.15 \pm 0.21^{\mathrm{aA}}$ \\
18 & $6.39 \pm 0.13^{\mathrm{aA}}$ & $6.34 \pm 0.06^{\mathrm{aAB}}$ & $6.29 \pm 0.11^{\mathrm{aA}}$ & $6.32 \pm 0.03^{\mathrm{aA}}$ & $6.2 \pm 0.07^{\mathrm{aA}}$ \\
24 & $6.52 \pm 0.12^{\mathrm{aA}}$ & $6.45 \pm 0.03^{\mathrm{abB}}$ & $6.33 \pm 0.1^{\mathrm{abA}}$ & $6.36 \pm 0.08^{\mathrm{abA}}$ & $6.27 \pm 0.16^{\mathrm{bA}}$ \\
\hline
\end{tabular}

${ }^{A-B}$ Means with different superscript letters in the same column indicate significant differences $(p<0.05) .{ }^{a-b}$ Means with different superscript letters in the same row indicate significant differences $(p<0.05)$. Data are expressed as means \pm standard deviation $(n=2)$.

as oleic acid equivalent.

\section{Determination of 2-thiobarbituric acid-reactive substances (TBARS)}

2-Thiobarbituric acid reactive substances (TBARS) were determined according to the method of Buege and Aust (1978). $0.5 \mathrm{~g}$ of fish fillet was homogenized in $10 \mathrm{ml}$ of the mixture containing TBA $(0.375 \mathrm{~g} / 100 \mathrm{ml})$, TCA $(15 \mathrm{~g} / 100 \mathrm{ml})$ and $\mathrm{HCl}(0.25 \mathrm{~mol} / \mathrm{l})$. The mixture was heated in the boiling water for $10 \mathrm{~min}$, followed by cooling with the running tap water. The mixture was centrifuged at $3600 \times g$ for 20 min and the absorbance was measured at $532 \mathrm{~nm}$ (Model 135 WFZ-UV-2100, UNICOTM, Shanghai, China). The TBARS value was calculated from the standard curve of malonaldehyde and expressed as $\mathrm{mg}$ malonaldehyde/kg sample.

\section{Total viable counts}

$10 \mathrm{~g}$ of each sample homogenate was diluted with $100 \mathrm{ml}$ of $1 \%$ $\mathrm{BPW}$ at $\mathrm{pH}$ 7.5. Serial dilutions were made until $10^{-7} \mathrm{~g} / \mathrm{ml}$ samples were obtained. A $1 \mathrm{ml}$ aliquot of each dilution was placed in a Petri dish and approximately $15 \mathrm{ml}$ plate count agar (PCA, Oxoid, CM325) was added. Appropriate decimal dilutions of the samples were prepared with the same diluents and $0.1 \mathrm{ml}$ aliquots of appropriate dilution were spread on the agar plates. Each Petri dish was carefully shaken, in order to achieve a homogeneous distribution of the sample. After several minutes all Petri dishes were inverted and placed in an oven at $37^{\circ} \mathrm{C}$ for $48 \mathrm{~h}$. After $48 \mathrm{~h}$ of incubation, all colonies were counted by hand, following the rules reported by Gilliland et al. (1976).

\section{Statistical analysis}

For data analysis, analysis of variance (ANOVA) was used. Significant differences were defined at $P<0.05$. Comparisons of group means were obtained using Duncan's multiple range tests. All statistical analysis was performed using SPSS version 19.0 for windows software (SPSS Inc., Chicago, IL).

\section{RESULTS AND DISCUSSION}

\section{Changes of $\mathrm{pH}$}

The $\mathrm{pH}$ value of smoked silver carp fillet was increased
$(P<0.05)$ with storage period (Table 1$)$. Its values ranged between 6.07 and 6.52 for both control and treated samples throughout the entire storage period. The limit of acceptability is usually 6.8 to 7.0 (Erkan et al., 2011). This phenomenon is presumably because of the production of basic nitrogen compounds such as ammonia, TMA, and/or other basic nitrogenous compounds caused by microbial activity or proteolytic enzymes in a food material (Fan et al., 2009).

\section{Water activity}

Changes in water activity (Aw) are shown in Table 2. Initially, the Aw for all samples was in the range of 0.84 to 0.93 , which increased significantly $(P<0.05)$ with storage time to a final range of 0.92 to 0.99 . The control samples showed higher water activity (Aw) value than the counterpart samples during time of storage. Water activity (aw) has its most useful application in predicting the growth of bacteria, yeast and mold. The knowledge of water activity is very important factor to guarantee the required stability towards microbial spoilage of the product and to ensure safety by avoiding any threat to the health of the consumer, this is because micro-organisms generally grow best between Aw values of $0.995-0.980$, while most microbes cease growth at $A w<0.900$. It is also necessary for the transport of nutrients and the removal of waste materials, to carry out enzymatic reactions, to synthesize cellular materials, and to take part in other biochemical reactions (Goksoy, et al., 2009).

\section{Color}

Color is one of the most important organoleptic characteristics. It influences the acceptability of the product and plays a major role in the purchase decision and evaluation of meat quality (O'Sullivan, et al., 2003).

$L^{*}$ values (lightness) decreased $(P<0.05)$ with the increase of storage time. Coordinates decreased from 84.36 on day 0 to 72.23 at the end of the experiment on 
Table 2. Water activity.

\begin{tabular}{lccccc}
\hline \multirow{2}{*}{ Storage time (days) } & \multicolumn{5}{c}{ Water activity } \\
\cline { 2 - 6 } & $\mathbf{C}$ & $\mathbf{T 1}$ & $\mathbf{T 2}$ & $\mathbf{T 3}$ & T4 \\
\hline 0 & $0.93 \pm 0^{\mathrm{bA}}$ & $0.93 \pm 0.01^{\mathrm{bA}}$ & $0.91 \pm 0^{\mathrm{bA}}$ & $0.91 \pm 0.02^{\mathrm{bA}}$ & $0.84 \pm 0^{\mathrm{aA}}$ \\
6 & $0.95 \pm 0.01^{\mathrm{bBA}}$ & $0.94 \pm 0.01^{\mathrm{bB}}$ & $0.92 \pm 0.03^{\mathrm{bA}}$ & $0.93 \pm 0.01^{\mathrm{bB}}$ & $0.85 \pm 0.03^{\mathrm{aBA}}$ \\
12 & $0.97 \pm 0.02^{\mathrm{cCB}}$ & $0.96 \pm 0.02^{\mathrm{cCB}}$ & $0.92 \pm 0^{\mathrm{bA}}$ & $0.94 \pm 0^{\mathrm{cbB}}$ & $0.87 \pm 0^{\mathrm{aBA}}$ \\
18 & $0.98 \pm 0.01^{\mathrm{dDC}}$ & $0.96 \pm 0.04^{\mathrm{cC}}$ & $0.93 \pm 0^{\mathrm{bA}}$ & $0.95 \pm 0.01^{\mathrm{bB}}$ & $0.89 \pm 0.028^{\mathrm{aCB}}$ \\
24 & $0.99 \pm 0.02^{\mathrm{aD}}$ & $0.97 \pm 0.03^{\mathrm{aC}}$ & $0.93 \pm 0.04^{\mathrm{aA}}$ & $0.95 \pm 0.05^{\mathrm{aB}}$ & $0.92 \pm 0^{\mathrm{aC}}$ \\
\hline${ }^{\mathrm{A}-\mathrm{D}}$ Means with different superscript letters in the same column indicate significant differences $(\mathrm{p}<0.05) .{ }^{\mathrm{a}-\mathrm{d}}$ Means \\
with different superscript letters in the same row indicate significant differences ( $\mathrm{p}<0.05)$. Data are expressed \\
as means \pm standard deviation ( $\mathrm{n}=2$ ).
\end{tabular}

Table 3. Colour measurements.

\begin{tabular}{|c|c|c|c|c|c|}
\hline \multirow{2}{*}{ Parameter/treatment } & \multicolumn{5}{|c|}{ Storage period (days) } \\
\hline & 0 & 6 & 12 & 18 & 24 \\
\hline \multicolumn{6}{|l|}{ L*-value(lightness) } \\
\hline Control & $84.36 \pm 0.51^{\mathrm{dE}}$ & $82.04 \pm 0.001^{\mathrm{dD}}$ & $79.28 \pm 0.03^{\mathrm{eC}}$ & $76.51 \pm 0.3^{\mathrm{eB}}$ & $72.23 \pm 0.13^{\mathrm{eA}}$ \\
\hline $\mathrm{T} 1$ & $83.16 \pm 0.06^{\mathrm{dcE}}$ & $80 \pm 0.85^{\mathrm{cD}}$ & $77.44 \pm 0.62^{d C}$ & $74.73 \pm 0.57^{\mathrm{dB}}$ & $70.68 \pm 0.45^{\mathrm{dA}}$ \\
\hline $\mathrm{T} 2$ & $79.28 \pm 1.81^{\mathrm{baD}}$ & $75.35 \pm 0.92^{\mathrm{bC}}$ & $74.22 \pm 0.03^{b c}$ & $68.43 \pm 0.14^{\mathrm{bB}}$ & $63.95 \pm 0.03^{\mathrm{bA}}$ \\
\hline T3 & $81.31 \pm 0.98^{\mathrm{cbE}}$ & $78.53 \pm 0.75^{\mathrm{cD}}$ & $75.74 \pm 0.48^{\mathrm{cC}}$ & $71.82 \pm 0.00^{\mathrm{cB}}$ & $68.15 \pm 0.21^{\mathrm{cA}}$ \\
\hline $\mathrm{T} 4$ & $77.75 \pm 0.21^{\mathrm{aE}}$ & $72.83 \pm 0.52^{\mathrm{aD}}$ & $71.47 \pm 0.75^{\mathrm{aC}}$ & $66.94 \pm 0.03^{\mathrm{aBC}}$ & $61.95 \pm 0.55^{\mathrm{aA}}$ \\
\hline \multicolumn{6}{|l|}{$a^{*}$-value (redness) } \\
\hline Control & $4.3 \pm 0.28^{\mathrm{dA}}$ & $5.62 \pm 0.91^{\mathrm{CB}}$ & $6.65 \pm 0.03^{\mathrm{eB}}$ & $8.12 \pm 0.25^{\mathrm{dC}}$ & $9.49 \pm 0.01^{\mathrm{eD}}$ \\
\hline $\mathrm{T} 1$ & $3.58 \pm 0.11^{\mathrm{cA}}$ & $5.16 \pm 0.23^{\mathrm{cB}}$ & $6.42 \pm 0.03^{\mathrm{dC}}$ & $7.69 \pm 0.13^{\mathrm{dD}}$ & $8.98 \pm 0.25^{\mathrm{dE}}$ \\
\hline $\mathrm{T} 2$ & $0.33 \pm 0.01^{\mathrm{aA}}$ & $2.09 \pm 0.14^{\mathrm{bB}}$ & $3.63 \pm 0.13^{b c}$ & $4.3 \pm 0.28^{\mathrm{bD}}$ & $5.91 \pm 0.001^{\mathrm{bE}}$ \\
\hline T3 & $2.24 \pm 0.08^{\mathrm{bA}}$ & $3 \pm 0.16^{\mathrm{bB}}$ & $4.37 \pm 0.11^{\mathrm{cC}}$ & $5.52 \pm 0.03^{\mathrm{CD}}$ & $6.93 \pm 0.04^{\mathrm{cE}}$ \\
\hline $\mathrm{T} 4$ & $0.35 \pm 0.01^{\mathrm{aA}}$ & $0.98 \pm 0.02^{\mathrm{aB}}$ & $2.01 \pm 0.01^{\mathrm{aC}}$ & $3.31 \pm 0.13^{\mathrm{aD}}$ & $4.92 \pm 0.04^{\mathrm{aE}}$ \\
\hline \multicolumn{6}{|l|}{$b^{*}$-value (yellowness) } \\
\hline Control & $27.12 \pm 1.24^{\mathrm{dC}}$ & $25.38 \pm 0.099^{\mathrm{dC}}$ & $22.63 \pm 1.26^{\mathrm{dB}}$ & $21.25 \pm 0.14^{\mathrm{dBA}}$ & $19.45 \pm 0.11^{\mathrm{eA}}$ \\
\hline $\mathrm{T} 1$ & $24.84 \pm 1.75^{\mathrm{dcD}}$ & $22.67 \pm 1.23^{\mathrm{cDC}}$ & $21.51 \pm 0.57^{\mathrm{dcCB}}$ & $19.51 \pm 0.51^{\mathrm{cBA}}$ & $18.23 \pm 0.17^{\mathrm{dA}}$ \\
\hline T2 & $21.45 \pm 0.21^{\mathrm{bD}}$ & $20.01 \pm 0.16^{\mathrm{bC}}$ & $18.74 \pm 0.13^{\mathrm{baB}}$ & $16.66 \pm 0.92^{\mathrm{baA}}$ & $15.77 \pm 0.06^{\mathrm{bA}}$ \\
\hline T3 & $23.12 \pm 0.96^{\mathrm{cbC}}$ & $21.4 \pm 0.14^{\mathrm{cbB}}$ & $19.99 \pm 0.41^{\mathrm{cbB}}$ & $17.93 \pm 0.68^{\mathrm{bA}}$ & $16.59 \pm 0.01^{\mathrm{cA}}$ \\
\hline $\mathrm{T} 4$ & $18.5 \pm 0.42^{\mathrm{aD}}$ & $17.69 \pm 0.58^{\mathrm{aDC}}$ & $17.49 \pm 0.28^{\mathrm{aC}}$ & $16.07 \pm 0.23^{\mathrm{aB}}$ & $15.12 \pm 0.001^{\mathrm{aA}}$ \\
\hline
\end{tabular}

the control samples, counterpart samples decreased from $77.75-83.16$ at day 0 to $61.95-70.68$ at the end of the experiment, depending on the treatment. Moreover, control samples showed higher values as compared to their counterpart samples (Table 3 ) but that difference was small and irrelevant. Many factors may contribute to more lightness on control samples than their counterpart samples, these include the concentration and type of pigments present (Viuda-Martos et al., 2010), water content, hygroscopicity of the material dissolved in the water matrix and surface water availability, but the pigment content and the fractions of MetMb and $\mathrm{OxyMb}$ were the most important factors for the variation in the $L^{*}$ value (Karlsson et al., 2006).

The $a^{*}$-value was found to increase $(P<0.05)$ in all samples as duration increased. Again the values in control samples were higher than counterpart samples with increasing storage time. The $a^{*}$-value in the control samples rose from 4.3 on day 1 to 9.49 at the end of the experiment. Treated samples rose from 0.33-3.58 to 4.92-8.98, depending on the treatment (Table 3 ). The increase of the $a^{*}$ value indicated that fish meat were redder, this 


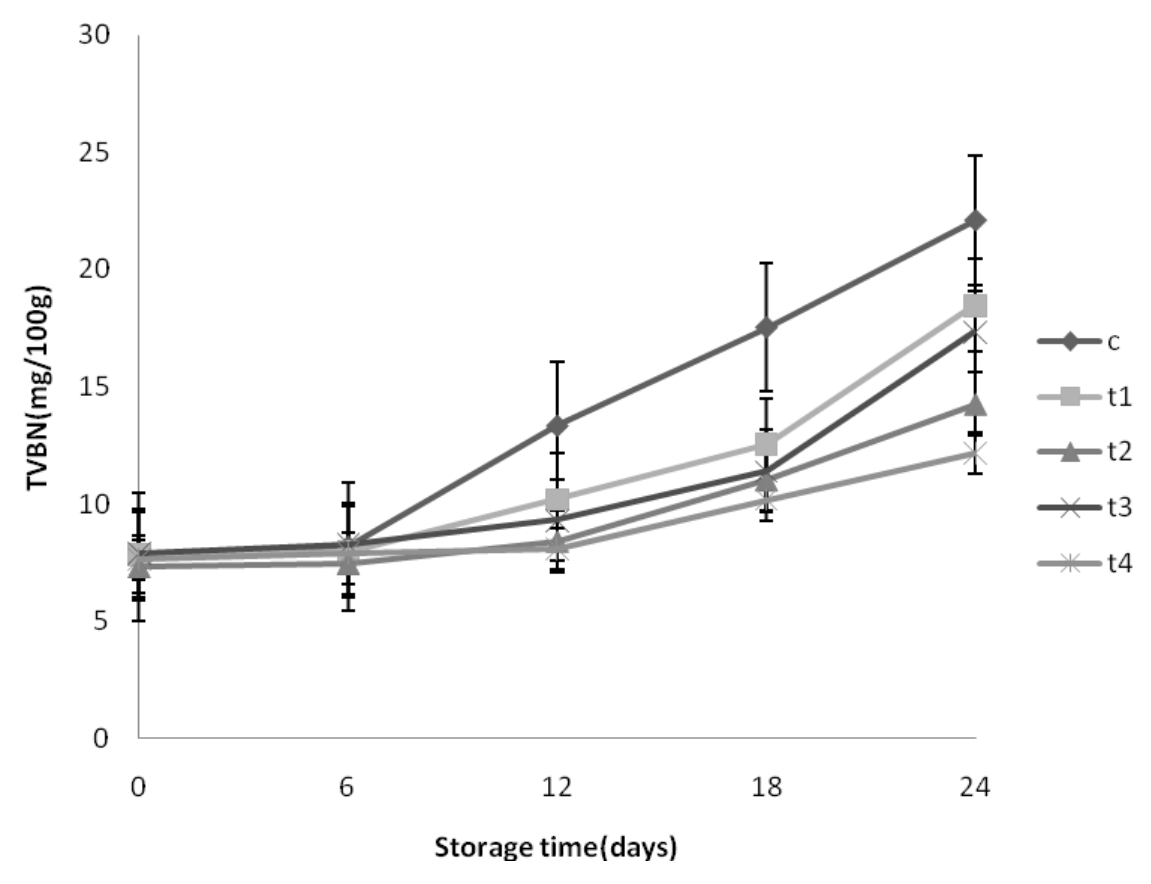

Figure 1. Total volatile basic nitrogen $(\mathrm{mg} / 100 \mathrm{~g})$.

could be due to less met-myoglobin formation (Faustman et al., 2010; Biswas et al., 2012). It is postulated that, spices are effective antioxidants that improve red color stability by inhibiting met-myoglobin formation in fish fillets (Allen and Cornforth, 2010). In the present study, the results do not establish the effectiveness of garlic and ginger as antioxidants and antimicrobials on red color stability.

For the yellow coordinate $\left(b^{*}\right)$, the value decreased $(P$ $<0.05$ ) in all samples during time of storage. Coordinates decreased from 27.12 on day 0 to 19.45 at the end of the experiment on the control samples, counterpart samples decreased from 18.5-24.84 at day zero to 15.12-18.23 at the end of the experiment, depending on the treatment (Table 3). Even though the magnitude of the differences was very small on all samples, the control samples showed higher yellowness than their counterpart samples. The differences for the yellow coordinate $\left(b^{*}\right)$, may be due to $\mathrm{pH}$, oxidation extent, water activity, etc. in the matrix which have the greatest influence on this coordinate in many foods (Cofrades et al., 2004).

\section{Total volatile base nitrogen (TVB-N)}

The TVB-N of fish is an indicator of the freshness of the raw material (Zhou et al., 2011). Changes in TVB-N of different samples during the entire storage period are shown in Figure 1. The initial TVB-N value of silver carp was in the range of 7.31 to $7.90 \mathrm{mg} / 100 \mathrm{~g}$. Similar results were also reported by Fan et al. (2009). TVB-N values of control samples showed significant $(P<0.05)$ differences from other samples on storage; as storage increased also its TVB-N value was higher than those other samples which increased more slowly than control samples after day 6 of storage. The TVB-N value of the control samples had already reached $12.32 \mathrm{mg} / 100 \mathrm{~g}$ on the day 12 of storage, while the values of counterpart samples did not reach this figure but was in the range of 8.08 to 10.2 $\mathrm{mg} / 100 \mathrm{~g}$. TVB-N values of samples T1, T2, T3 and T4 on the 24th day of storage were 18.48, 14.27, 17.36 and $12.16 \mathrm{mg} / 100 \mathrm{~g}$, respectively, while TVB-N value of control samples on the 24 th day was $22.8 \mathrm{mg} / 100 \mathrm{~g}$. TVB$\mathrm{N}$ values of all samples were lower than $25 \mathrm{mg} / 100 \mathrm{~g}$ which was considered as the threshold for a good-quality fish product, high TVB-N values are unacceptable and are associated with unpleasant smell in the meat (Limbo et al., 2009). Assumably, this is because of the impact of the various treatments of TVB-N, which primarily includes nitrogen from ammonia, TMA, and dimethylamine which reflects the extent of degradation of proteins and non protein nitrogenous compounds which can be explained by proteolysis, due to enzymatic and microbial activities in the samples on storage (Erkan and Ozden, 2008). In the present study, the results establish the effectiveness of garlic and ginger as antioxidants and antimicrobials due to reduction in TVB-N on treated samples as observed, it is supposed that the spices used to treat silver carp were involved in TVB-N reduction.

\section{Free fatty acids}

The initial FFA values were in the range of 7.19 to 7.9 


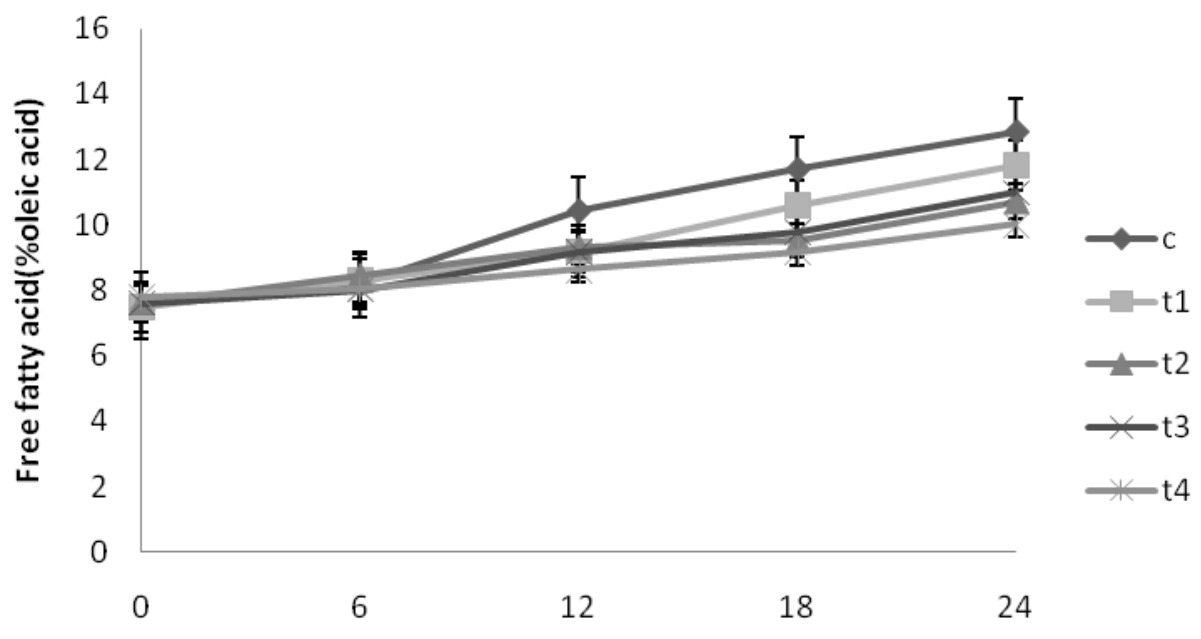

Storage time(days)

Figure 2. Free fatty acids (percentage oleic acid).

(oleic acid percentage) for all samples. FFA values increased with storage time (Figure 2); however the values in the control samples were higher than other samples during storage. Significant statistical differences were found between the treated samples and control samples $(P<0.05)$ after day 12 of storage. At the end of the storage period (day 24), values of FFA on control samples were found to be 12.83 (oleic acid percentage) which is higher than counterpart samples which were found to be 11.82, 10.72, 10.98 and 10.01 (oleic acid percentage) for $\mathrm{T} 1, \mathrm{~T} 2, \mathrm{~T} 3$ and $\mathrm{T} 4$, respectively. Accumulation of FFA is said to contribute to off flavor of the product and cause textural alterations by complexing with protein (Siddaiah et al., 2001). The results established the effectiveness of garlic and ginger as antioxidants which were greater in activities to inhibit the synthesis of free fatty acid in the treated samples than control samples on 24 days of storage.

\section{Thiobarbituric acid reactive substances (TBARS)}

Fish meat is particularly susceptible to oxidative changes because of the processing conditions, exposure of unsaturated fat and proteins to molecular oxygen. 2Thiobarbituric acid (TBA) is widely used as an indicator of degree of lipid oxidation, and the presence of TBA reactive substances is due to the second stage autooxidation (Rezaei and Hosseini, 2008) during which peroxides are oxidized to aldehydes and ketones (Lindsay, 1991). The TBARS values of all silver carp samples increased as storage time increased, the increase of TBARS values in fish meat with increasing storage time is normal (Rong et al., 2009) (Figure 3). Significant differences were found between control samples and counterpart samples $(P<0.05)$ after day 6 of storage. The mean TBARS values of control were found to be $1.56 \mathrm{mgMA} / \mathrm{kg}$ of fish flesh which is higher than those of other samples which were found to be 1.2, 1.02, 1.1 and $0.93 \mathrm{mgMA} / \mathrm{kg}$ for T1, T2, T3 and T4, respectively, at day 24 of storage. There are two possible reasons for this phenomenon in the effectiveness of this product: 1, reduction in TBARS using garlic and ginger is related to peroxide-scavenging enzyme activity, which could reduce unsaturated fatty acid and total unsaturated fatty acid oxidation and 2 , some active components in the garlic and ginger may involve desaturase and elongase activities (Mariutti et al., 2008).

\section{Total viable counts}

As shown, initial total viable counts (TVC) in all samples was in the range of 2.20 to $2.28 \log _{10} \mathrm{CFU} / \mathrm{g}$ indicating very good fish quality, the value was found to increase ( $p$ $<0.05$ ) but remained below $7 \log _{10} \mathrm{CFU} / \mathrm{g}$ in all treatments for 24 days of storage, which is the Maximal Permissible Limit (MPL) for TVC recommended (ICMSF, 1986; Ojagh et al., 2010) in all samples. The values in the control samples were higher than their counterpart samples with storage time (Table 4). The increase of TVC in fish flesh during storage has been demonstrated by Bahmani et al. (2011). The high levels of microorganisms shown on control samples from day 6 of storage, resulted into significant differences $(P<0.05)$ in TVC when compared with counterpart samples due to the strong antimicrobial activity of the organ sulfur compounds and other active components contained in garlic and ginger (Lu et al., 2011). TVC is the most common microbiological method aimed to detect and enumerate 


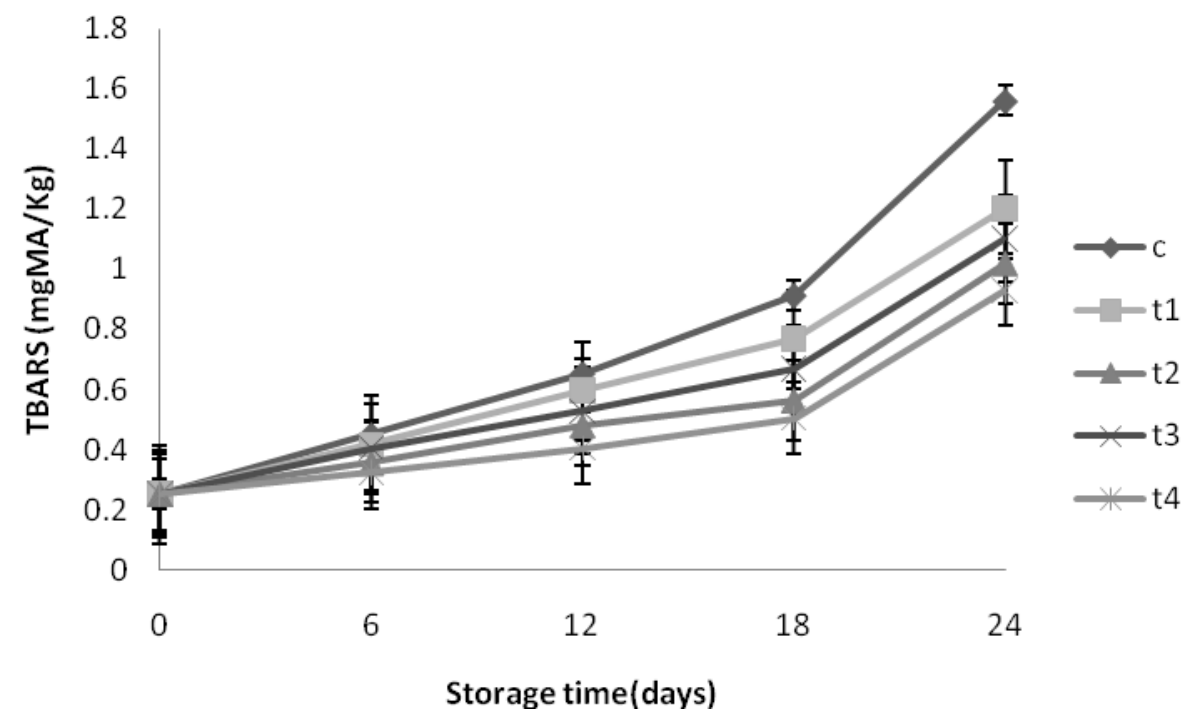

Figure 3. 2-Thiobarbituric acid-reactive substances (mgMA/kg).

Table 4. Total viable counts $\left(\log _{10} \mathrm{CFU} / \mathrm{g}\right)$.

\begin{tabular}{lccccc}
\hline \multirow{2}{*}{ Parameter } & \multicolumn{5}{c}{ Storage time (days) } \\
\cline { 2 - 6 } & $\mathbf{0}$ & $\mathbf{6}$ & $\mathbf{1 2}$ & $\mathbf{1 8}$ & $\mathbf{2 4}$ \\
\hline $\mathrm{C}$ & $2.26 \pm 0.04^{\mathrm{aA}}$ & $3.53 \pm 0.45^{\mathrm{dB}}$ & $5.57 \pm 0.38^{\mathrm{CC}}$ & $6.12 \pm 0.11^{\mathrm{eD}}$ & $6.91 \pm 0.27^{\mathrm{CE}}$ \\
$\mathrm{T} 1$ & $2.23 \pm 0.01^{\mathrm{aA}}$ & $3.08 \pm 0.16^{\mathrm{cB}}$ & $3.49 \pm 0.06^{\mathrm{bC}}$ & $4.16 \pm 0.18^{\mathrm{dD}}$ & $4.42 \pm 0.03^{\mathrm{bE}}$ \\
$\mathrm{T} 2$ & $2.26 \pm 0.11^{\mathrm{aA}}$ & $2.71 \pm 0.14^{\mathrm{bB}}$ & $3.18 \pm 0.1^{\mathrm{aC}}$ & $3.72 \pm 0.07^{\mathrm{bD}}$ & $4.24 \pm 0.04^{\mathrm{baE}}$ \\
$\mathrm{T} 3$ & $2.20 \pm 0.09^{\mathrm{aA}}$ & $2.86 \pm 0.03^{\mathrm{bB}}$ & $3.47 \pm 0^{\mathrm{bC}}$ & $3.91 \pm 0.01^{\mathrm{cD}}$ & $4.38 \pm 0.07^{\mathrm{bE}}$ \\
T4 & $2.28 \pm 0^{\mathrm{aA}}$ & $2.49 \pm 0.09^{\mathrm{aA}}$ & $2.9 \pm 0.04^{\mathrm{aB}}$ & $3.44 \pm 0.17^{\mathrm{aC}}$ & $4 \pm 0.01^{\mathrm{aD}}$ \\
\hline
\end{tabular}

${ }^{\mathrm{a}-\mathrm{e}}$ Means with different superscript letters in the same column indicate significant differences $(p<0.05)$. ${ }^{A-E}$ Means with different superscript letters in the same row indicate significant differences $(p<0.05)$. Data are expressed as means \pm standard deviation $(n=2)$.

high proportion of the microbial population as possible. In practice, this usually means mesophilic, aerobic or facultatively anaerobic bacteria, which account for the major part of the microflora in fish. A TVC method can only provide an estimate of the microbial population based on those cells that are recoverable under the test conditions. Some viable cells may not be recoverable by any existing method, while others may only grow at low temperatures, in the presence of specific growth factors, or in the absence of oxygen (Fulford et al., 2004)

\section{Conclusion}

From the above results, it can be concluded that both garlic and ginger in fresh and powder form provide antioxidant and antimicrobial benefits to liquid smoked silver carp during chilled storage for 24 days. Therefore, it is suggested that garlic and ginger, as a natural herb, could be used to extend the shelf life of meat products, providing the consumer with food containing natural additives, which might be seen more healthful than those of synthetic origin. Further research is required to focus on understanding the mechanisms of action, in particular concentrations of active ingredients of both ginger and garlic in either powder or fresh form which applied to liquid smoked fish products.

\section{ACKNOWLEDGEMENT}

This research was financially supported by the earmarked fund for China Agriculture Research System (CARS-46).

\section{REFERENCES}

Alcicek Z (2013). Effects of Different Liquid Smoke Flavor Levels on the 
Shelf Life of Venus Clam (Chamelea Gallina, L 1758) Meat. J Food Process Preserv. doi: 10.1111/jfpp.12052

Allen K, Cornforth D (2010). Comparison of spice-derived antioxidants and metal chelators on fresh beef color stability. Meat Science 85(4): 613-619.

Antonacopoulos N, Vyncke W (1989). Determination of volatile basic nitrogen in fish: A third collaborative study by the West European Fish Technologists' Association (WEFTA). Zeitschrift für LebensmittelUntersuchung und Forschung 189(4): 309-316.

Bahmani ZA, Rezai M, Hosseini SV, Regenstein JM, Bohme K, Alishahi $A$, Yadollahi $F$ (2011). Chilled storage of golden gray mullet (Liza aurata). LWT - Food Sci. Technol. 44(9): 1894-1900.

Biswas AK, Chatli MK, Sahoo J (2012). Antioxidant potential of curry (Murraya koenigii L.) and mint (Mentha spicata) leaf extracts and their effect on colour and oxidative stability of raw ground pork meat during refrigeration storage. Food Chem. 133(2): 467-472.

Buege JA, Aust SD (1978). Microsomal lipid peroxidation. Methods in Enzymology. F. Sidney and P. Lester, Academic Press. Volume 52: 302-310.

Cofrades S, Serrano A, Ayo J, Solas MT, Carballo J, Colmenero FJ (2004). Restructured beef with different proportions of walnut as affected by meat particle size. Eur. Food Res. Technol. 218(3): 230236.

Erkan N, Ozden O (2007). Proximate composition and mineral contents in aqua cultured sea bass (Dicentrarchus labrax), sea bream (Sparus aurata) analyzed by ICP-MS. Food Chem. 102(3): 721-725.

Erkan N, Ozden O (2008). Quality assessment of whole and gutted sardines (Sardina pilchardus) stored in ice. Int. J. Food Sci. Technol. 43(9): 1549-1559.

Erkan N, Tosun SY, Ulusoy S, Uretener G (2011). The use of thyme and laurel essential oil treatments to extend the shelf life of bluefish (Pomatomus saltatrix) during storage in ice. Journal für Verbraucherschutz und Lebensmittelsicherheit 6(1): 39-48.

Faustman C, Sun Q, Mancini R, Suman SP (2010). Myoglobin and lipid oxidation interactions: Mechanistic bases and control. Meat Sci. 86(1): 86-94.

Fulford MR, Walker JT, Martin MV, Marsh PD (2004). Total viable counts, ATP, and endotoxin levels as potential markers of microbial contamination of dental unit water systems. Br. Dent. J. 196:157 159.

Gilliland SE, Busta FF, Brinda JJ, Campbell JE (1976). Aerobic Plate Count M.L. Speck (Ed.), Compendium of Methods for the Microbiological Examination of Foods, America Public Health Association, Inc., Washington, pp. 107-131

Hattula T, Elfving K, Mroueh UM, Luoma T (2001). Use of Liquid Smoke Flavouring as an Alternative to Traditional Flue Gas Smoking of Rainbow Trout Fillets (Oncorhynchus mykiss). LWT - Food Sci. Technol. 34(8): 521-525.

Hu Y, Xia W, Ge C (2008). Characterization of fermented silver carp sausages inoculated with mixed starter culture. LWT - Food Sci. Technol. 41(4): 730-738.

ICMSF (1986). International commission on microbiological specifications for foods. Sampling plans for fish and shellfish. In ICMSF (Ed.), ICMSF, Microorganisms in foods. Sampling for microbiological analysis: Principles and scientific applications (Vol. 2, 2nd ed.). Toronto, Canada: University of Toronto Press.

Kirk S, Sawyer R (1991). Pearson's composition and analysis of foods, Longman Group Ltd.

Lanier TC, Hart K, Martin RE (1991). A manual of standard methods for measuring and specifying the properties of surimi, National Fisheries Institute, Washington, DC.

Limbo S, Sinelli N, Torri L, Riva M. (2009). Freshness decay and shelf life predictive modelling of European sea bass (Dicentrarchus labrax) applying chemical methods and electronic nose. LWT - Food Sci. Technol. 42(5): 977-984.
Lindsay RC (1991). Flavour of fish. Paper presented at 8th World Congress of Food Science \& Technology, 29th September-4th October, Toronto, Canada.

Lu X, Rasco BA, Jabal JMF, Aston DE, Lin M, Konkel ME (2011). Investigating Antibacterial Effects of Garlic (Allium sativum) Concentrate and Garlic-Derived Organosulfur Compounds on Campylobacter jejuni by Using Fourier Transform Infrared Spectroscopy, Raman Spectroscopy, and Electron Microscopy. Appl. Environ. Microbiol. 77(15): 5257-5269.

Mariutti LB, Orlien V, Bragagnolo N, Skibsted LH (2008). Effect of sage and garlic on lipid oxidation in high-pressure processed chicken meat. Eur. Food Res. Technol. 227(2): 337-344.

Muratore G, Licciardello F (2005). Effect of Vacuum and Modified Atmosphere Packaging on the Shelf-life of Liquid-smoked Swordfish (Xiphias gladius) Slices. J. Food Sci. 70(5): C359-C363.

Naseri M, Rezaei M (2012). Lipid Changes During Long-Term Storage of Canned Sprat. J. Aquat. Food Prod. Technol. 21(1): 48-58.

Ojagh SM, Rezaei M, Razavi SH, Hosseini SMH (2010). Effect of chitosan coatings enriched with cinnamon oil on the quality of refrigerated rainbow trout. Food Chem. 120(1):193-198.

O'Sullivan MG, Byrne DV, Martens H, Gidskehaug LH, Andersen HJ, Martens M (2003). Evaluation of pork colour: prediction of visual sensory quality of meat from instrumental and computer vision methods of colour analysis. Meat Sci. 65(2): 909-918.

Rezaei M, Hosseini FS (2008). Quality Assessment of Farmed Rainbow Trout (Oncorhynchus mykiss) during Chilled Storage. J. Food Sci. 73(6): H93-H96.

Rong CX, Chang-hu X, Qi L, Bang-zhong Y (2009). Microbiological, chemical and sensory assessment of (I) whole ungutted, (II) whole gutted and (III) filleted tilapia (Oreochromis niloticus) during refrigerated storage. Int. J. Food Sci. Technol. 44(11): 2243-2248.

Uhart M, Maks N, Ravishankar S (2006). Effect of spices on growth and survival of salmonella typhimurium dt 104 in ground beef stored at 4 and 8c. J. Food Saf. 26(2):115-125.

Varlet V, Serot T, Knockaert C, Cornet J, Cardinal M, Monteau F, Bizec $B$, Prost C (2007). Organoleptic characterization and PAH content of salmon (Salmo salar) fillets smoked according to four industrial smoking techniques. J. Sci. Food Agric. 87(5): 847-854.

Visciano P, Perugini M, Conte F, Amorena M (2008). Polycyclic aromatic hydrocarbons in farmed rainbow trout (Oncorhynchus mykiss) processed by traditional flue gas smoking and by liquid smoke flavourings. Food Chem. Toxicol. 46(5):1409-1413.

Viuda-Martos M, Ruiz-Navajas Y, Fernandez-Lopez J, Perez-Alvarez JA (2010). Effect of added citrus fibre and spice essential oils on quality characteristics and shelf-life of mortadella. Meat Sci. 85(3): 568-576.

Vyncke W (1981). pH of fish muscle comparison of methods, Western European Fish Technologists' Association (WEFTA), Copenhagen, Denmark.

Yanishlieva NV, Marinova E, Pokorny J (2006). Natural antioxidants from herbs and spices. European Journal of Lipid Science and Technology 108(9): 776-793.

Zhou R, Liu Y, Xie J, Wang X (2011). Effects of combined treatment of electrolysed water and chitosan on the quality attributes and myofibril degradation in farmed obscure puffer fish (Takifugu obscurus) during refrigerated storage. Food Chem. 129(4): 1660-1666. 